\title{
PENGGUGURAN TUNTUTAN FILIPINA KE ATAS SABAH DAN GERAKAN PEMISAHAN SABAH PADA DEKAD KEDUA KEPIMPINAN FERDINAND MARCOS, 1977 - 1980
}

\author{
Norizan Binti Kadir \\ Suffian Mansor
}

\begin{abstract}
Foreign relations between Philippines and Malaysia, particularly after the formation of Malaysia showed a volatile situation in relation to the numerous crisis either directly or indirectly related to the Philippines' claim on Sabah. Since the official announcement by the President of the Philippines, President Macapagal of the claim on Sabah in 1962, the bilateral relations between the Philippine and the Federation of Malaya became a "thorn in the flesh" as there were no effective instrument to stop the Philippines desire to claim Sabah. Until the first decade of the reign of President Marcos, bilateral relations between Philippine and Malaysia was again troubled due to the raising of the issues related to the Philippines' claim on Sabah. With the attitude and stance adopted by Marcos that became more aggressive and unpredictable with several unilateral actions, including the Jabidah Massacre incident, the Malaysian government's response became more firm in order to defend its sovereign territory.
\end{abstract}

\section{Pengenalan}

Setelah berakhirnya era pemerintahan Diosdado Macapagal sebagai Presiden Filipina, pemerintahan Filipina kemudiannya diambil alih 
oleh Presiden Ferdinand Marcos setelah beliau berjaya menang dalam pilihan raya Republik Filipina pada tahun 1965. Kemenangan beliau dalam pilihan raya sekali lagi diulangi pada tahun 1969 apabila menjadi presiden untuk penggal kedua sehingga tahun 1986 sebelum digulingkan oleh Corazon Aquino pada Februari 1986. Ketika penggal kedua era pemerintahan Marcos, pendirian Marcos yang terlalu agresif tentang soal tuntutan ke atas Sabah telah menyukarkan lagi proses pemulihan hubungan diplomatik Filipina-Malaysia yang tercetus sejak pengumuman pengisytiharan ke atas Sabah dibuat oleh Presiden Macapagal.

Berbeza dengan penggal pertama Presiden Marcos memerintah Filipina di mana pada akhir penggal kedua dan ketiga pemerintahannya memperlihatkan sikap beliau yang lebih sederhana dan bertolak ansur terhadap persoalan Sabah. Pada tahap ini, beliau mulai akur dan sedar dengan hakikat bahawa tuntutan Filipina ke atas Sabah tidak memberikan sebarang keuntungan jangka masa panjang mahupun pendek malah hanya menjejaskan hubungan bilateralnya dengan Malaysia. Perasaan curiga dan sangsi yang berlarutan antara FilipinaMalaysia untuk menjalankan kerjasama khususnya dalam aspek persempadanan dan pembangunan ekonomi sering dihantui oleh isu Sabah yang tidak pernah berkesudahan.

Oleh itu, pada tahun 1977 ketika Persidangan ASEAN di Kuala Lumpur, Presiden Marcos telah membuat pengumuman rasminya berhubung pengguguran tuntutan Filipina ke atas Sabah. Kesediaan Filipina untuk menggugurkan tuntutan tersebut telah disambut baik oleh semua delegasi yang hadir dalam persidangan tersebut malahan yang lebih utama adalah ia menjadi berita gembira buat Malaysia yang sudah sekian lama cuba untuk menjernihkan semula hubungan diplomatik Malaysia-Filipina. Walau bagaimanapun, Malaysia hakikatnya sedar bahawa, selagi tiada tindakan yang konkrit dan definitif dilakukan oleh Filipina untuk merealisasikan kenyataan tersebut, maka pengumuman pengguguran oleh Marcos itu tidak memberikan sebarang makna, malahan tidak lebih dari satu propaganda.

Meskipun dijanjikan oleh pihak Marcos sendiri bahawa beliau akan mengambil langkah-langkah yang sewajarnya untuk menggugurkan tuntutan tersebut, namun ia tidaklah semudah yang disangkakan. Pelbagai halangan dan cabaran yang terpaksa ditempuhi untuk merealisasikannya kerana beliau sendiri terpaksa berhadapan dengan ramai pihak yang berkepentingan tentang isu Sabah sama ada di Filipina mahupun di Malaysia. Antara cabaran dan halangan utama ke arah pengguguran tuntutan tersebut adalah kesukaran Filipina untuk meminda perlembagaannya yang berkaitan tuntutannya ke atas Sabah kerana jika klausa yang berkenaan dihapuskan, ia akan menyebabkan usaha Filipina untuk menuntut Pulau Spratly juga turut terkubur. Di 
samping itu, halangan turut diterima daripada waris-waris Sultan Sulu serta krisis dalaman Sabah ekoran kemasukan imigran Filipina sehingga mencetuskan gerakan pemisahan Sabah.

\section{Latar Belakang Tuntutan Filipina ke atas Sabah Sebelum 1977}

Ketika Filipina mencapai kemerdekaan pada tahun 1946 sehinggalah tahun 1962 tiada sebarang tuntutan rasmi ke atas Sabah dibuat oleh Republik Filipina. Keutuhan dan kedaulatan Sabah kekal terjamin dalam tempoh tersebut meskipun masih terdapat tuntutan yang dibuat oleh Sultan Sulu dan warisnya. Antara asas tuntutan Sultan Sulu dan warisnya untuk menuntut Sabah pada ketika itu adalah bersandarkan kepada perjanjian yang ditandatangani oleh Sultan Jamalul 'Azam dengan Baron de Overbeck dan Alfred Dent pada 22 Januari 1878. 'Wariswaris Sultan Sulu mendakwa pemberian tersebut adalah bersifat pajakan dan bukannya penyerahan untuk selama-lamanya. ${ }^{2}$

Walau bagaimanapun, tuntutan-tuntutan tersebut gagal menarik minat Filipina untuk menyokong tuntutan yang dibuat oleh waris Sultan Sulu tersebut. Sehinggalah pada 22 Januari 1962, Macapagal mengemukakan aide-memoire tuntutan ke atas Sabah kepada British. ${ }^{3}$ Ketika Presiden Macapagal mengumumkan hasrat Filipina untuk menuntut Sabah pada Jun 1962, Filipina hakikatnya masih belum mengkaji secara komprehensif mengenai kes tuntutan tersebut. Hanya selepas aide-memoire tersebut dihantar, barulah jawatankuasa untuk mengkaji kes tuntutan ditubuhkan. Antara yang terlibat secara langsung mengkaji kes tuntutan tersebut termasuklah Orendain yang menggunakan bahan dari Department of Foreign Affairs (DFA), Menteri Simeon Roxas, ahli kongres Salonga dan duta Filipina Quintero yang juga seorang peguam serta diikuti dengan pelantikan sekumpulan pakar khas oleh DFA. ${ }^{4}$

Tuntutan tersebut juga merupakan satu usaha Filipina untuk menghalang rancangan pembentukan Malaysia yang diumumkan oleh Tunku Abdul Rahman pada 27 Mei 1961 yang melibatkan penggabungan negeri Tanah Melayu, Singapura, Brunei, Sabah dan Sarawak. Pengisytiharan pembentukan Malaysia ini telah memberikan tamparan yang cukup hebat buat Republik Filipina kerana hasratnya untuk memiliki Sabah hampir menemui kegagalan. Pertikaian mengenai hak kedaulatan ke atas Sabah antara kerajaan Filipina dan Malaysia kemudiannya berlanjutan sehinggalah ke era pemerintahan Presiden Ferdinand Marcos yang mengamalkan pendekatan yang lebih agresif untuk menuntut semula Sabah. Antaranya termasuklah merancang misi sulit untuk menyerang Sabah yang digelar sebagai "Operasi Merdeka" pada Mac 1968. ${ }^{5}$ Peristiwa yang dikenali sebagai Jabidah Massacre atau Corregidor Incident tersebut telah mengorbankan kira-kira 28 hingga ke 
64 orang Muslim Filipina yang direkrut dalam latihan ketenteraan di Pulau Corregidor. ${ }^{6}$ Berikutan peristiwa tersebut, hubungan diplomatik Filipina-Malaysia sekali lagi terputus kerana tiada penyelesaian dipersetujui mengenai konflik tersebut. Setelah hampir sedekad, barulah Presiden Marcos mengumumkan pengguguran tuntutan ke atas Sabah ketika berlangsungnya persidangan Association of Southeast Asian Nations (ASEAN) di Kuala Lumpur pada tahun 1977.

\section{Sikap dan Polisi Kepimpinan Marcos}

Corak dasar luar Filipina ketika kepimpinan Presiden Marcos dalam fasa kedua pemerintahannya memperlihatkan sikapnya yang lebih berhatihati, pragmatik dan lebih mengutamakan matlamat dan kepentingan dalaman negara termasuklah aspek politik, ekonomi dan keselamatan yang kemudiannya dilanjutkan kepada kepentingannya di peringkat antarabangsa. Malahan beliau juga sudah mula memperlihatkan sikapnya yang mahu berbaik-baik dengan Malaysia serta sanggup mengetepikan tuntutannya ke atas Sabah demi menjaga hubungan baiknya dengan Malaysia.

Ketika persidangan Association of Southeast Asian Nations (ASEAN) di Kuala Lumpur pada tahun 1977 dan kemudiannya di Manila, Presiden Marcos telah membuat satu pengumuman penting demi menjaga kepentingan dan semangat kesatuan dalam ASEAN dengan mengumumkan bahawa, "taking definite steps to eliminate one of the burdens of ASEAN - the claim of the Philippine Republic to Sabah". ${ }^{7}$ Pengumuman menggemparkan tersebut merupakan isu yang paling menonjol dan telah meraih perhatian daripada semua negara anggota dalam persidangan kedua ASEAN. Menurut Marcos, Filipina akan mengambil langkahlangkah yang sewajarnya bagi menggugurkan tuntutannya ke atas Sabah. Marcos memberi jaminan bahawa pihaknya akan menyiapkan kenyataan dan laporan rasmi mengenainya serta memaklumkan proses tersebut dijangka hanya akan mengambil masa beberapa bulan sahaja. ${ }^{8}$ Namun begitu, beliau menjelaskan tiada perjanjian khusus perlu dibuat mengenai pengguguran tersebut dan tidak membenarkan ia dikaitkan dengan isu-isu dan permasalahan lainnya.

Keadaan ini telah menimbulkan persoalan tentang kaedah untuk mengawal sempadan kedua-dua negara dengan ketiadaan Border Crossing Agreement (Perjanjian Lintasan Sempadan) ditandatangani antara Filipina dan Malaysia. Keperluan untuk kedua-dua negara tersebut mengadakan perjanjian sempadan tersebut amatlah penting bagi memastikan sebarang masalah yang berkaitan sempadan seperti pencerobohan, pelanunan dan kehadiran pendatang dapat diselesaikan dengan baik serta tidak menjejaskan hubungan dua hala FilipinaMalaysia. ${ }^{9}$ 
Walau bagaimanapun, tindakannya yang cuba untuk tidak lagi meneruskan tuntutannya ke atas Sabah masih dipertikaikan oleh Malaysia. Malaysia masih tidak berpuas hati dengan kompromi tersebut dan bertegas supaya Filipina bertindak lebih jauh iaitu dengan membuat pindaan terhadap perlembagaannya. ${ }^{10}$ Bagaimanapun, kelewatan Marcos melaksanakannya menyebabkan hubungan tegang antara Filipina-Malaysia berterusan. Ketika pertemuan antara W. Bentley, Duta British di Manila dengan Jeneral Romulo di Manila pada Februari 1978, Bentley telah mengajukan pertanyaan langkah-langkah seterusnya yang akan diambil oleh Filipina bagi menggugurkan tuntutannya ke atas Sabah. ${ }^{11}$

Romulo dalam responsnya memaklumkan bahawa beliau sendiri tidak pasti sama ada masih ada tindakan lain yang harus dilakukan. Hal ini kerana menurut beliau, Marcos sudah pun mengumumkan hasratnya untuk menggugurkan tuntutannya ke atas Sabah ketika Persidangan ASEAN di Kuala Lumpur dan di Manila serta mengulangi sekali lagi pendirian yang sama ketika Perhimpunan Bangsa-Bangsa Bersatu (PBB) pada tahun 1977. Justeru, Bentley turut mencadangkan perkara yang sama seperti yang dikemukakan oleh Malaysia supaya dibuat pindaan terhadap Perlembagaan Filipina. ${ }^{12}$

Romulo dalam jawapan yang diberikan kepada Bentley juga menerima cadangan tersebut namun perkara tersebut berkemungkinan dapat direalisasikan selepas pemilihan dalam Interim Legislative Assembly pada bulan Februari berikutnya. Kemungkinan wujudnya perselisihan pendapat dalam kalangan ahli dewan perhimpunan yang menentang keputusan pengguguran tuntutan ke atas Sabah, namun di akhirnya mereka tetap akan menyokong keputusan Marcos sama ada secara rela atau terpaksa. Justeru, langkah definitif dan segera dengan mengadakan perbincangan rasmi mengenai Sabah dalam perhimpunan tersebut perlu dilaksanakan, seandainya Presiden Marcos benar-benar mahu merealisasikan hasratnya untuk menggugurkan tuntutan ke atas Sabah. Dalam pertemuan yang sama juga Bentley turut mencadangkan jika pindaan perlembagaan Filipina berjaya dilaksanakan, Filipina wajar menandatangani Border Crossing Agreement dengan Malaysia dan sekali lagi cadangan tersebut dipersetujui Romulo. ${ }^{13}$

Walau bagaimanapun, Filipina masih belum dapat menerima sepenuhnya cadangan supaya dilakukan pindaan ke atas Perlembagaan Filipina berhubung pengguguran tuntutan Filipina ke atas Sabah memandangkan terdapat hanya satu artikel relevan yang menyatakan secara jelas mengenai tuntutan ke atas Sabah iaitu :

The national territory comprises the Philippine archipelago, with all the islands and waters embraced therein, and all the other territories belonging to the Philippines by historic right or legal title... ${ }^{14}$ 
Hal ini demikian kerana, jika artikel tersebut dihapuskan, ia akan menyebabkan Filipina berhadapan dengan kesukaran dalam usahanya untuk menuntut Pulau Spratly. Namun, salah satu langkah bijak yang boleh dilakukan untuk memastikan Filipina boleh terus kekal menuntut Pulau Spratly iaitu dengan menggantikan perkataan territories kepada islands. Tidak dapat dinafikan bahawa, jika usaha ke arah meminda perlembagaan Filipina dipandang serius oleh Filipina, ia sekurangkurangnya dapat menghapuskan perasaan curiga dan prejudis Malaysia terhadap Filipina.

Namun begitu, setelah lebih dua bulan pengumuman pengguguran ke atas Sabah dibuat oleh Marcos, tiada sebarang langkah selanjutnya diambil oleh Marcos khususnya untuk meminda Perlembagaan Filipina yang berkaitan Sabah. Tiada juga tindakan dilakukan selepas pembentukan Interim Legislative Assembly yang baharu seperti yang didakwa Romulo ketika pertemuannya dengan Bentley. ${ }^{15}$ Janji yang sama turut diberikan oleh Romulo kepada Menteri Hal Ehwal Luar dan Komanwel British, Goromny-Roberts. Namun, Goromny menganggap kenyataan Romulo tersebut hanyalah sambil lewa dan tidak serius serta sedar sikapnya yang seolah-olah mahu menghentikan perbincangan mengenai perkara tersebut dan cuba mengalih perbualan kepada isu yang lain. ${ }^{16}$ Malahan, ketika pertanyaan yang sama turut diajukan oleh Duta British di Manila kepada Gonzales, ${ }^{17}$ beliau menjelaskan tiada keperluan untuk meminda Perlembagaan Filipina sambil menegaskan dekri yang diumumkan oleh Presiden Marcos berhubung pengguguran tuntutan tersebut sudah memadai. Dalam nada yang tegas, beliau juga meneguhkan pendiriannya dengan berkata, " you pays your money and you takes your choice" ${ }^{18}$

Lebih membingungkan juga, Kementerian Hal Ehwal Luar Negeri Filipina tidak mempunyai sebarang tanggungjawab langsung terhadap isu pengguguran tuntutan ke atas Sabah kecuali hanya menjalankan fungsi peripheral dalam hal-hal berkaitan dengannya. ${ }^{19}$ Segala keputusan dan maklumat mengenai isu tersebut berada sepenuhnya di bawah pentadbiran Pejabat Presiden. Jelasnya, isu tersebut langsung tidak disebut dan dibincangkan dalam perbincangan-perbincangan rasmi pentadbiran Republik Filipina. ${ }^{20}$

Terdapat beberapa kemungkinan di sebalik sikap yang ditunjukkan menerusi kepimpinan Marcos tersebut. Pertama, pengumuman tuntutan tersebut hanyalah helah dan muslihat Marcos bagi meraih semula sokongan negara-negara anggota ASEAN dan kembali menjalinkan kerjasama yang menguntungkan dengan Malaysia. Kedua, Marcos mahu mengelakkan isu Sabah menjadi bahan kempen dalam pilihan raya Filipina akan datang. Jika isu Sabah terus dibahaskan di Dewan 
Perwakilan, ia dikhuatiri akan menyebabkan persoalan Sabah akan sekali lagi menjadi perhatian dan tumpuan media massa di Filipina. Dengan itu, sekali gus akan menyukarkan usaha ke arah untuk menjalinkan semula hubungan baik Filipina-Malaysia. Dengan situasi di Selatan Filipina yang tidak menentu, ia secara tidak langsung menyebabkan hubungan bilateral Manila-Kuala Lumpur-Sabah menjadi bertambah kompleks. ${ }^{21}$

Oleh sebab terlalu mengharapkan perkembangan terkini mengenai isu pengguguran tuntutan Filipina ke atas Sabah, Alastair Baillie sekali lagi mengajukan soalan mengenai isu tersebut kepada pegawai di Interim National Assembly pada 12 Jun 1978 dalam persidangannya pada hari ke-30. ${ }^{22}$ Menurut pegawai yang berkenaan, proses perbincangan pada ketika itu masih tertumpu pada persoalan bayaran pampasan atau ganti rugi yang harus dibayar oleh Kerajaan Malaysia kepada waris-waris Sultan Sulu. Perkembangan ini benar-benar mengejutkan kerana Filipina masih lagi akur dengan kehendak dan tuntutan wariswaris Sultan Sulu sedangkan Malaysia begitu mengharapkan kejujuran Filipina dalam soal pengguguran tuntutan tersebut tanpa mengenakan sebarang syarat-syarat yang tidak sepatutnya. Perasaan curiga terhadap keikhlasan Marcos turut disepakati oleh duta-duta Malaysia dan Indonesia seperti yang dinyatakan oleh Baillie sebagai, "my Malaysian and Indonesian colleagues can throw no light on the reasons but the former are still not wholly convinced of Marcos's sincerity". ${ }^{23}$ Keduanya, terdapat terlalu ramai waris-waris Sultan Sulu yang menuntut Sabah, maka adalah amat tidak munasabah sama sekali bayaran pampasan tersebut boleh ditunaikan oleh kerajaan Malaysia.

Menyedari hubungan Filipina-Malaysia yang masih memperlihatkan keadaan yang tidak stabil khususnya mengenai persoalan Sabah, pegawai British R. P. Flower di Pejabat Pesuruhjaya Tinggi British di Kuala Lumpur telah memanggil Halim, Ketua Jabatan Asia Tenggara di Wisma Putra pada 9 Oktober 1978 untuk mendapatkan perkembangan terkini mengenai hubungan Filipina-Malaysia. ${ }^{24} \mathrm{Halim}$ memaklumkan bahawa Malaysia tidak menerima sebarang makluman rasmi terlebih dahulu daripada Presiden Marcos berhubung dengan pengguguran tuntutan Filipina ke atas Sabah meskipun pengumuman mengenainya sudah dibuat oleh Marcos setahun sebelumnya. Jelasnya, Marcos hanyalah mengumumkan keputusannya untuk menggugurkan tuntutan ke atas Sabah namun tidak disusuli oleh tindakan rasmi yang boleh menjamin kes tuntutan tersebut tidak akan lagi berulang pada masa akan datang. Lebih membingungkan lagi apabila pegawai Marcos sendiri di Jabatan Hal Ehwal Luar Negeri dilihat hanya mendiamkan diri seperti tidak tahu menahu mengenai perancangan Marcos. ${ }^{25}$ 
Malaysia menganggap ketiadaan kenyataan bertulis dan rasmi dibuat mengenai pengguguran tuntutan tersebut serta hanya menzahirkan idea yang mentah yang belum diperhalusi dengan mendalam sebagai usaha yang tidak serius yang dikemukakan oleh Marcos. ${ }^{26}$ Sehingga tahun 1979, tiada langkah signifikan yang dilaksanakan oleh Filipina bagi merealisasikan pengumuman yang dibuat oleh Marcos ketika Persidangan ASEAN di Kuala Lumpur. Sementara itu, Malaysia yang merupakan salah satu negara anggota dalam Organisation of Islamic Cooperation (OIC) bertegas dengan polisinya iaitu untuk tidak menjalinkan sebarang kerjasama dengan Filipina selagi situasi di Selatan Filipina masih belum jelas dan tiada penyelesaian yang ampuh terhadapnya dilakukan. ${ }^{27}$ Dalam masa yang sama, Malaysia juga dilihat sangat berhati-hati dalam mengeluarkan sebarang kenyataan pasca ucapan Marcos mengenai pengguguran tuntutan ke atas Sabah. Hal ini turut diakui oleh Duta British di Manila yang menyifatkan sikap Malaysia sebagai, "the Malaysians here have always dodged the issue and never spelt out their views in any explicit manner". ${ }^{28}$

Sikap saling mencurigai dan sangsi terhadap antara kedua-dua pihak, Filipina dan Malaysia ini menyebabkan proses perdamaian yang hakiki semakin sukar dicapai apatah lagi dengan situasi di Selatan Filipina dan perkembangan sosiopolitik di Sabah yang tidak stabil berikutan berlakunya pelbagai krisis kepimpinan. Halim turut mengakui hakikat bahawa sememangnya wujud tembok penghalang antara hubungan Filipina-Malaysia ekoran isu tuntutan Filipina ke atas Sabah yang tiada berkesudahan sehinggakan Manila, ibu negara Filipina menjadi satu-satunya ibu negara anggota ASEAN yang tidak dilawati oleh Tun Hussein Onn ketika di awal pemerintahannya. ${ }^{29}$

Walau bagaimanapun, Malaysia tidak lagi terlalu bimbang mengenai tuntutan tersebut kerana terbukti sejak sekian lama penguasaannya ke atas Sabah sudah tidak dapat dipertikaikan dan dicabar lagi. Namun, Malaysia masih belum mahu memperbaiki hubungan tersebut sehinggalah kerajaan Filipina mengambil langkah konkrit bagi menghentikan perselisihan tersebut. Dengan itu, Malaysia masih dibelenggu oleh perasaan curiganya terhadap kejujuran dan kesanggupan Marcos untuk menggugurkan tuntutan Filipina ke atas Sabah. ${ }^{30}$ Hal ini kerana Malaysia juga amat sedar bahawa jika tiada tindakan dilakukan bagi meminda penetapan wilayah yang termaktub di dalam Perlembagaan Filipina yang sengaja dipinda pada tahun 1972 bagi membolehkan tuntutan ke atas Sabah dibuat, maka hasrat pengguguran tuntutan tersebut tidak lebih dari propaganda Filipina semata-mata. Jelasnya, adalah tidak munasabah sama sekali untuk Malaysia mengetepikan kaedah efektif bagi memberikan tekanan 
kepada Filipina sehinggalah tuntutannya ke atas Sabah digugurkan secara formal dan jelas.

\section{Halangan dan Cabaran Pengguguran Tuntutan}

Sehingga akhir tahun 1980-an, terdapat pelbagai cabaran dan halangan ke arah pengguguran tuntutan Filipina ke atas Sabah. Antara halangan dan cabaran terbesar datangnya dari pihak-pihak yang berkepentingan terhadap tuntutan tersebut. Di sebalik kepentingan Filipina yang bermatlamatkan untuk mempertahankan kedaulatan wilayahnya, kekayaan sumber alam semula jadi dan menjaga imej serta "air muka" Filipina di mata dunia daripada dianggap lemah kerana gagal menyuarakan tuntutannya ke atas Sabah, terdapat juga kepentingankepentingan yang bersifat peribadi oleh individu-individu yang terlibat secara langsung dan tidak langsung dalam tuntutan Filipina ke atas Sabah.

Pihak-pihak berkepentingan yang dimaksudkan adalah dalam kalangan ahli politikus Filipina termasuklah Marcos sendiri sebagai individu yang mempunyai kepentingan terbesar berdasarkan kedudukannya sebagai Presiden Filipina yang menuntut Sabah bagi pihak Filipina dan Kesultanan Sulu. ${ }^{31}$ Kepentingan yang dimaksudkan adalah dari sudut keuntungan yang bakal diterimanya jika bayaran ganti rugi atau lump-sum dibayar oleh kerajaan Malaysia kepada Filipina supaya Filipina menggugurkan tuntutannya ke atas Sabah. Hal yang sama turut dinyatakan oleh S. B.Olver, Pegawai British di bahagian Research Department, Southeast Asia kepada Kathleen Kazer yang mengingatkan kembali tentang tuntutan-tuntutan lampau berbentuk lump-sum daripada Filipina terhadap British. Antaranya adalah pada tahun 1957 iaitu apabila Filipina membuat tuntutan sebanyak £10 juta daripada Colonial Office sebagai bayaran ganti rugi jika mahu Filipina menggugurkan tuntutannya ke atas Sabah. ${ }^{32}$ Pihak berkepentingan lain yang turut mengambil kesempatan di sebalik tuntutan Filipina ke atas Sabah adalah golongan yang terlibat dalam kegiatan penyeludupan antara Filipina dan Malaysia. ${ }^{33}$ Golongan ini melihat hubungan baik Filipina-Malaysia hanya akan menjejaskan perjalanan aktiviti penyeludupan mereka terutamanya jika perjanjian kawalan persempadanan dilaksanakan oleh kedua-dua buah negara tersebut. $^{34}$

Cabaran lain yang dihadapi Marcos bagi menggugurkan tuntutannya ke atas Sabah adalah kerana wujudnya pengaruh dan penentangan daripada waris-waris Sultan Sulu dan penuntut lain supaya Filipina tidak menggugurkan tuntutan ke atas Sabah atau terus memberikan sokongan kepada waris-waris Sultan Sulu untuk menuntut 
Sabah. Dalam tahun 1970-an tuntutan ke atas Sabah diteruskan oleh waris-waris Sultan Sulu yang berkepentingan namun sokongan turut diberikan kepada Filipina untuk menuntut Sabah. Antaranya, Datu Haji Rodinood yang mendakwa dirinya sebagai Raja Muda Sulu Datu Haji Rodinood Sultan Julhasbi Kiram yang menetap di Kota Kinabalu, Sabah menuntut supaya pertikaian mengenai Sabah diselesaikan segera melalui rundingan persahabatan. ${ }^{35}$

Dalam suratnya kepada Menteri Hal Ehwal Luar dan Komanwel British Goromny-Roberts, Datu Haji Rodinood telah mengemukakan tuntutannya ke atas Sabah dengan mendakwa dirinya sebagai keturunan Sultan Sulu yang sah. Beliau turut memohon supaya diaturkan suatu pertemuan antara waris-waris Sultan Sulu dengan mana-mana pemimpin tertinggi Malaysia bagi menyelesaikan kes tuntutan ke atas Sabah. ${ }^{36}$ Bersempena dengan 100 tahun penyerahan wilayah Pantai Timur Sabah oleh Sultan Jamalul 'Alam ${ }^{37}$ kepada North Borneo Chartered Company (NBCC) pada 22 Januari 1878, Datu Rodinood meminta supaya Sabah diserahkan semula kepada waris Kesultanan Sulu yang menurut beliau negeri tersebut telah dikuasai secara tidak sah dan menyalahi undang-undang. Menurut beliau, Sabah masih kekal sebagai milik Kesultanan Sulu yang sah meskipun wujud perjanjian penyerahan di antara NBCC kepada Crown Colony sehingga membawa kepada pembentukan Persekutuan Malaysia pada 16 September 1963. Menurutnya:

Right of sovereignty as well as proprietary rights thereof remain vested in the Sultanate of Sulu; that any transactions by the North Borneo Chartered Company with the British Crown or the British Crown with the Federated States of Malaysia do not affect the rights of the Sultanate of Sulu. No period of time will validate the acts of the holder or possessor since the Sultanate of Sulu is not a party to the transaction there over. The rule of law on the subject is clear that the British North Borneo Company must return or restore such possessor to the Sultanate of Sulu..$^{38}$

Meskipun beliau mendakwa Kesultanan Sulu mempunyai hak yang sah ke atas Sabah namun beliau turut menyokong tindakan Republik Filipina menyuarakan tuntutan ke atas Sabah. Hal ini kerana, beliau beranggapan tuntutan yang dibuat oleh Filipina tersebut sebagai mewakili hak dan kepentingan Kesultanan Sulu dan rakyat Filipina amnya. Beliau turut menggugut jika kerajaan Malaysia masih berdegil untuk menyerahkan semula Sabah kepada Filipina, sokongan terhadap Marcos untuk membawa kes tuntutan tersebut ke International Court of Justice (ICJ) tidak dapat dielakkan lagi. ${ }^{39}$ Justeru, kata dua diberikan kepada British supaya segera menyerahkan Sabah kepada Kesultanan 
Sulu sebelum tindakan penilaian dan penghakiman diambil oleh pihak ICJ. ${ }^{40}$

Pada masa yang sama, Datu Haji Rodinood turut mencadangkan supaya diadakan pertemuan khas sama ada di Kuala Lumpur atau di Manila bagi membentuk suatu kontrak perjanjian baru antara wariswaris Sultan Sulu dan penuntut lain seperti Nakoda Sangkalang bagi mengiktiraf dan mengesahkan pemilik sah ke atas kedaulatan Sabah. ${ }^{41}$ Perbincangan mengenai bayaran pampasan turut dibincangkan dalam pertemuan tersebut jika sekiranya penuntut-penuntut tersebut menginginkan sejumlah bayaran sebagai ganti rugi kepada pemilikan Sabah oleh British dan Kerajaan Malaysia. ${ }^{42}$

Walau bagaimanapun, Pejabat Foreign Colonial Office mengambil pendirian untuk tidak mengiktiraf dan membalas surat tersebut. Tindakan tersebut turut dipersetujui oleh R. P. Flower, Pesuruhjaya British di Kuala Lumpur yang menyifatkan ia sebagai tindakan yang bijak. ${ }^{43}$ Apatah lagi pihak British dan Kuala Lumpur sendiri mendapati tiada sebarang rekod mengenai Datu Rodinood yang dapat mengesahkan beliau sebagai waris Sultan Sulu yang sah. ${ }^{44}$ Kuala Lumpur juga menganggap usaha untuk menuntut Sabah oleh waris Sultan Sulu tersebut bukanlah suatu perkara yang mengejutkan kerana sebelumnya lagi berpuluh-puluh tuntutan terhadap Sabah pernah dibuat oleh ramai waris Sultan Sulu yang mendakwa diri mereka sebagai waris sultan yang sah. ${ }^{45}$

Selanjutnya, pada 12 November 1978 telah ditandatangani satu memorandum perjanjian oleh 57 orang waris Sultan Sulu yang berasal dari salasilah keturunan Sultan Sulu dari keluarga Aranan yang berakhir di Sultan Badaruddin I, Sultan Agbimuddin I dan Sultan Israil I. ${ }^{46}$ Pengesahan status semua waris Sultan Sulu tersebut dikatakan telah diluluskan oleh ahli Majlis Rumah Bicara daripada keturunan Sultan Badaruddin I, Sultan Alimuddin I, Sultan Muda Mohammad Israil I sehingga Sultan Tuban Wizer Han Sultan Alimuddin I. Memorandum tersebut merupakan satu pengisytiharan rasmi daripada waris-waris Sultan Sulu bagi menuntut Sabah. ${ }^{47}$

Memorandum yang dikemukakan kepada pihak British dan Kerajaan Malaysia serta salinan kepada pejabat Presiden Marcos ini menjelaskan tiga perkara penting iaitu sejarah penyerahan wilayah Pantai Timur Sabah oleh Sultan Brunei kepada Sultan Sulu, penguasaan orang Tirun di Sabah sehinggalah membawa kekalahan orang Tirun kepada Sultan Sulu. Memorandum itu mengulangi pendirian yang sama seperti tuntutan-tuntutan yang dibuat pada tahun-tahun sebelumnya iaitu penyerahan Pantai Timur Sabah oleh Sultan Muaddin, Sultan Brunei kepada Sultan Alimuddin, anak kepada Sultan Badaruddin I adalah sebagai membalas jasanya yang membantu Brunei mengalahkan 
Sultan Abdul Mubin dalam perang saudara di Brunei. Peristiwa penyerahan tersebut turut tercatat di dalam Salasilah Sulu yang ditulis oleh Pangiran Tumbaga pada tahun $1698 .^{48}$

Sementara itu, tuntutan waris-waris Sultan Sulu tersebut yang melibatkan seluruh Sabah pula didakwa bertitik tolak daripada kisah penguasaan orang Tirun ke atas sebahagian besar wilayah di Sabah sehinggalah ke kawasan Balikpapan yang juga didakwa sebagai milik Kesultanan Sulu. ${ }^{49}$ Dakwaan ini jelas sangat bertentangan daripada kenyataan sebenar yakni wilayah-wilayah lain di Sabah pada ketika itu telah lama dikuasai oleh Kesultanan Brunei. ${ }^{50}$

Keduanya, memorandum tersebut menjelaskan mengenai susur galur waris keturunan Sultan Sulu yang sah sehingga ke Sultan Alimuddin I. Kesinambungan salasilah ini terhenti setakat Sultan Muda Mohammad Israil I sahaja kerana beliau dikatakan memiliki hak dan kekuasaan yang terawal ke atas seluruh wilayah di Sabah yakni tidak hanya terhad kepada wilayah Pantai Timur Sabah sahaja. Keturunan Sultan Muda Mohammad Israil I seterusnya adalah Sultan Azimuddin Sali III, Sultan Tumenggong Bantilan Tuban Alimuddin IV, Sultan Amirhamja Ramir Amirhan Tuban Aranan Alimuddin V atau lebih dikenali sebagai Sultan Aranan dan kemudiannya digantikan oleh Datu Pangiran Anni Titoo Tuban. Selanjutnya ialah Datu Pangiran Anni, Sultan Tuban Wizer dan seterusnya Sultan Alimuddin I iaitu Datu J. S. Tuban pada tahun 1917. Justeru, memorandum tersebut hanya mengiktiraf waris-waris Kesultanan Sulu yang bersambung salasilahnya hingga ke Sultan Muda Mohammad Israil I. ${ }^{51}$

Perkara ketiga pula dijelaskan mengenai kedudukan waris-waris Sultan Sulu tersebut sebagai warganegara Republik Filipina dan menjadi subjek kepada Kerajaan Filipina di bawah kepimpinan Presiden Marcos serta tertakluk kepada perundangan Filipina. ${ }^{52}$ Kenyataan ini dibuat sebagai penegasan bahawa meskipun tuntutan berasingan daripada Filipina dibuat ke atas Sabah namun waris-waris Sultan Sulu tersebut masih menganggap tidak wujud pemisahan antara hasrat dan matlamat kedua-dua pihak tersebut dalam menuntut Sabah. Hakikat sebenar di sebalik pengumuman memorandum itu adalah bagi memberi desakan kepada Presiden Marcos supaya tidak menggugurkan tuntutan ke atas Sabah dan sekalipun Republik Filipina enggan meneruskan tuntutan tersebut, waris-waris Sultan Sulu tersebut mengharapkan sokongan Filipina untuk membenarkan mereka terus menuntut Sabah.

\section{Gerakan Pemisahan Sabah}

Meskipun rundingan mengenai Border Crossing Agreement masih terus berjalan pada 1978, namun Malaysia dilihat mengamalkan sikap 
sederhana dan tidak tergopoh-gopoh dalam membuat persetujuan bersama dalam perjanjian tersebut. Hal ini dilakukan kerana mengambil kira sikap Filipina yang seperti "acuh tidak acuh" dalam menggerakkan usaha ke arah rundingan dengan Moro National Liberation Front (MNLF) dan melaksanakan prosedur formal bagi merealisasikan ucapan Marcos untuk menggugurkan tuntutan ke atas Sabah. Hakikat ini turut diakui oleh pihak British kerana tiada sebarang tanda-tanda yang menunjukkan Filipina merancang untuk mengambil langkah sewajarnya bagi merealisasikan dua perkara tersebut khususnya bertindak meminda Perlembagaan Filipina berhubung pengguguran tuntutan Filipina ke atas Sabah. ${ }^{53}$ Dengan kes pengguguran tuntutan Filipina ke atas Sabah yang masih tidak sepenuhnya direalisasikan dan kehadiran lebih kurang 100,000 orang pelarian Filipina di Sabah, namun rundingan Border Crossing Agreement masih belum menunjukkan tanda-tanda kedua-dua negara bertikai untuk mencapai persepakatan. ${ }^{54}$

Pada Oktober 1978, satu pertemuan sulit telah diadakan antara Harris Salleh, Ketua Menteri Sabah dan Menteri Pertahanan Filipina berdasarkan maklumat yang diterima oleh Duta British di Manila daripada ejen perisikannya. Meskipun tidak jelas tentang tujuan lawatan tersebut, namun Duta British di Manila, A. T. Baillie di dalam suratnya kepada Jabatan Asia Tenggara memaklumkan bahawa sesuatu yang pelik sedang berlaku dan beliau menjangkakan pertemuan tersebut mempunyai kaitan dengan rancangan yang dinamakan sebagai Sabah Project. ${ }^{55}$ Projek yang dipercayai didalangi oleh Kementerian Pertahanan Filipina, Enrile benar-benar mencetuskan kebimbangan kepada pihak British sehingga meramalkan wujudnya satu kumpulan sama ada dalam kalangan masyarakat Sabah atau Filipina yang sedang melakukan persiapan untuk menyerang Sabah. Tanggapan tersebut timbul berikutan kewujudan pangkalan dan pusat operasi MNLF di Sabah yang lengkap dengan pelbagai sumber dan bekalan untuk peperangan. Baillie dalam suratnya turut menyatakan kerisauannya mengenai rancangan sulit tersebut sebagai, "the 'Sabah project' - if it exists - could make things worse" ${ }^{56}$ Hubungan Filipina-Malaysia juga dijangkakan berakhir dengan keretakan yang semakin sukar untuk diperbaiki.

Walau bagaimanapun, pejuang pemisah Bangsa Moro yang masih mengekalkan Sabah sebagai pusat dan pangkalan operasinya menambahkan lagi kerisauan Malaysia. Ini kerana, jika ia tidak dibanteras sepenuhnya, dikhuatiri pejuang-pejuang Bangsa Moro akan menyerang dan menguasai Sabah memandangkan Sabah sudah menjadi pangkalan ketenteraan pejuang-pejuang MNLF. ${ }^{57}$ Justeru, pada tahun 1978, Tan Sri Ghazali Shafie telah mengadakan lawatan ke Tripoli, Libya dan memberikan pesanan kepada Libya supaya tidak campur tangan dan terlibat sama sekali dalam memberikan apa-apa 
sokongan dalam pilihan raya di Malaysia akan datang. ${ }^{58}$ Ghazali menyatakan pandangannya bahawa Libya pernah burnt their fingers demi memberikan sokongan dan bantuan kepada pejuang-pejuang MNLF dan tidak mustahil perkara yang sama juga akan dilakukan di Malaysia melainkan Libya sudah mengambil pengajaran daripada kisah lalu. Apabila ditanya oleh R. P. Flower sama ada Libya boleh dipercayai dan akan memegang janjinya itu Ghazali menegaskan ia bukannya soal kepercayaan, tetapi hanyalah sekadar memaklumkan peringatan tersebut kepada Libya. ${ }^{59}$

\section{Kesimpulan}

Kesediaan Presiden Marcos untuk menggugurkan tuntutan ke atas Sabah telah memberikan nafas baru dalam proses pemulihan hubungan dua hala Filipina-Malaysia. Keputusan ini sememangnya sudah lama ditunggu-tunggu oleh Kerajaan Malaysia mahupun British kerana tiada kesudahannya jika Filipina masih meneruskan tuntutannya ke atas Sabah. Kesukaran kedua-dua pihak untuk menjalinkan kerjasama khususnya melibatkan aspek keselamatan sempadan, sering kali dibelenggu oleh isu tuntutan yang tidak bernoktah. Meskipun terdapat pelbagai halangan dan cabaran di sebalik proses pengguguran tersebut, namun ia sekurang-kurangnya menjadi langkah pertama ke arah pengharmonian hubungan baik Filipina-Malaysia.

Isu tuntutan Filipina ke atas Sabah, bukan sahaja mengeruhkan hubungan dua hala Filipina-Malaysia malah turut membangkitkan pelbagai masalah dalaman negara yang lain termasuklah krisis di Selatan Filipina dan gerakan pemisahan di Sabah yang berakar daripada perjuangan Bangsa Moro untuk mendapatkan wilayah autonomi. Bagi mereka, Sabah juga merupakan sebahagian daripada kekuasaan Kesultanan Sulu suatu ketika dahulu dan ia masih kekal milik Kesultanan Sulu hingga kini. Oleh itu, tidak hairanlah jika seandainya berdasarkan keyakinan itulah usaha dan gerakan sulit dilakukan bagi memisahkan Sabah dari Malaysia. Justeru, sama ada Filipina mahupun Malaysia, kedua-duanya terpaksa menanggung risiko akibat isu tuntutan yang berpanjangan. Hanya melalui perjanjian yang definitif mengenai pengguguran tuntutan Filipina ke atas Sabah kemudiannya disusuli dengan perjanjian tidak menceroboh, akta persempadanan dan perjanjian damai Filipina-Bangsa Moro maka segala isu yang berkaitan dengannya akan dapat diselesaikan. 


\section{Nota}

1 Surat Perjanjian 1878, Sultan Jamalul 'Alam kepada Baron Von Overbeck.

$2 \quad$ K. G. Tregonning.'The Philippine Claim To Sabah',Journal Of The Malaysian

Branch Of Royal Asiatic Society, Vol. XLIII, Part 1, 1970, hlm. 168.

3 Philippine's Claim to North Borneo (Sabah), Vol. 1. (1960). Manila: Bureau of Printing, lampiran no. 30.

4 Noble, L.G., Philippine Policy Toward Sabah A Claim To Independence, Arizona: The University of Arizona Press, 1977, hlm. 109.

5 W. K. Che Man, Muslim Separatism: The Moros of Southern Philippines And The Malays of Southern Thailand, Singapore: Oxford University Press, 1990, hlm. 74 .

6 Ibid.

7 Surat daripada Duta Australia di Manila, D. G. Nutter kepada Menteri Hal Ehwal Luar Negeri Australia, Andrew Peacock bertajuk Developments In Philippine Foreign Policy, 5 April 1978. Terlampir di dalam FCO 15/2396, South East Asian Department: Foreign Policy of the Philippines. Pengumuman Marcos mengenai pengguguran tuntutan Filipina ke atas Sabah telah mencetuskan polemik dan provokasi oleh rakyat Filipina khususnya alumni undang-undang dari University of the Philippines yang menganggap tindakan tersebut sebagai tidak wajar. Lihat New Straits Times, 'No Claim Bonus', 9 Oktober 1978. Rujuk juga Surat Pegawai Southeast Asia Section (Research Department), S. B. Olver kepada Kathleen Kazer, Southeast Asia Department, 24 Mei 1978.

$8 \quad$ New Straits Times, 'No Claim Bonus', 9 Oktober 1978.

9 Surat Duta British di Manila, A. T. Baillie kepada Southeast Asia Department bertajuk The Southwestern Philippines Problem, 12 September 1978. Lihat juga Rammani A/P Karupiah, "Hubungan Filipina-Malaysia Semasa Pemerintahan Presiden Ferdinand Marcos 1965-1986", Tesis Sarjana Jabatan Sejarah, Fakulti Sastera dan Sains Sosial, Universiti Malaya, 2012, hlm. 86.

10 Surat daripada Duta Australia di Manila, D. G. Nutter kepada Menteri Hal Ehwal Luar Negeri Australia, Andrew Peacock bertajuk Developments In Philippine Foreign Policy, 5 April 1978.

11 Surat W. Bentley Kepada Foreign \& Commonwealth Office bertajuk General Romulo, 28 Februari 1978.

12 Ibid.

13 Ibid.

14 Philippine Constitution. Lihat juga Surat Duta British di Manila kepada R. N. Pierce, Southeast Asia Department bertajuk Philippine Claim to Sabah, 27 Mac 1978.

15 Walaupun sememangnya terdapat penentangan daripada pemimpinpemimpin pembangkang terhadap keputusan Marcos yang menggugurkan tuntutan ke atas Sabah, namun ia belum dapat mempengaruhi apatah lagi menghalang keputusan yang telah dibuat oleh Marcos. Lihat Surat A. T. Baillie, Pejabat Kedutaan British di Manila kepada R. N. Pierce bertajuk The Philippine Claim To Sabah, 13 Februari 1978. Rujuk juga Nestor Martinez 
Nisperos, Philippines Foreign Policy on the North Borneo Question. Tesis Ph.D, University of Pittsburgh, 1969, hlm. 210.

16 Surat Duta British di Manila kepada R. N. Pierce, Southeast Asia Department bertajuk Philippine Claim to Sabah, 27 Mac 1978.

17 Gonzales adalah Ketua Pengarah Protokol di Jabatan Hal Ehwal Luar Negeri yang juga merupakan individu keempat paling berpengaruh dalam hierarki Kementerian Hal Ehwal Luar Negeri Filipina serta menjadi tempat rujukan utama Presiden Marcos dalam penentuan dasar luarnya. Ibid.

18 Ibid

19 Surat A. T. Baillie, Pejabat Kedutaan British di Manila kepada B. Smith Esq, Southeast Asian Department, Foreign \& Commonwealth Office bertajuk South Western Philippines Muslim Problem, 17 Julai 1978. Ibid.

21 Sokongan dan bantuan yang diberikan oleh Tun Mustapha kepada pejuang Moro National Liberation Front (MNLF) tambah mengeruhkan lagi hubungan dua hala Filipina-Malaysia. Tun Datu Mustapha tidak hanya bertindak membawa masuk pejuang MNLF dan menyediakan latihan ketenteraan di Sabah tetapi juga turut menjadikan Sabah sebagai pusat operasi atau pangkalan MNLF serta kawasan berundur jika MNLF diserang oleh pihak musuh. Peter Kreuzer dan Rainer Werning, Voices From Moro Land, Selangor: Strategic Information and Research Development Centre, 2007, hlm. xviii.

22 Surat A. T. Baillie, Pejabat Kedutaan British di Manila kepada B. Smith Esq, Southeast Asian Department, Foreign \& Commonwealth Office bertajuk South Western Philippines Muslim Problem, 17 Julai 1978. Filipina hakikatnya sedar bahawa isu tuntutan ke atas Sabah sudah lama berlalu dan hubungan bilateralnya dengan Malaysia juga seharusnya sudah pulih. Lihat FCO 15/2396, Southeast Asian Department: Foreign Policy Of The Philippines.

23 Ibid.

24 Surat R. P. Flower, Pesuruhjaya British di Kuala Lumpur kepada R. N. Peirce, Foreign \& Commonwealth Office bertajuk Malaysia-Philippine Relations, 10 Oktober 1978.

25 Surat A. T. Baillie, Pejabat Kedutaan British di Manila kepada R. N. Pierce bertajuk The Philippine Claim To Sabah, 13 Februari 1978.

26 Surat R. P. Flower, Pesuruhjaya British di Kuala Lumpur kepada R. N. Peirce, Foreign \& Commonwealth Office bertajuk Malaysia-Philippine Relations, 10 Oktober 1978. Ketiadaan tindakan susulan yang bersifat konkrit dan rasmi daripada Kerajaan Filipina telah menimbulkan keraguan kepada penduduk Malaysia sehingga ia dilihat tidak lebih dari retorik Marcos semata-mata. Lihat New Straits Times, 'No Claim Bonus', 9 Oktober 1978.

$27 \quad$ Ibid.

28 Surat Duta British di Manila kepada R. N. Pierce, Southeast Asia Department bertajuk Philippine Claim to Sabah, 27 Mac 1978. 
Surat R. P. Flower, Pesuruhjaya British di Kuala Lumpur kepada R. N. Peirce, Foreign \& Commonwealth Office bertajuk Malaysia-Philippine Relations, 10 Oktober 1978.

30 Berhubung hal ini, semua pihak termasuklah British dan Malaysia sendiri tidak mempunyai sebarang jawapan tentang niat dan tujuan sebenar Marcos mengumumkan polisi pengguguran tuntutan Filipina ke atas Sabah namun tidak pula disertai dengan apa-apa usaha ke arah merealisasikan perkara tersebut secara formal. Lihat Surat R. N. Pierce, Southeast Asia Department bertajuk Philippine Claim to Sabah, 8 Mac 1978. Surat Pegawai Southeast Asia Section (Research Department), S. B. Olver kepada Kathleen Kazer, Southeast Asia Department, 24 Mei 1978. Ibid.

33 Ibid

34 Ibid

35 Surat Datu Haji Rodinood Sultan JulhasbiKiram kepada GoromnyRoberts, 12 Mei 1978. Ibid.

Ibid.

Ibid.

Ibid.

Ibid.

Ibid.

Ibid.

Surat Pesuruhjaya British di Kuala Lumpur kepada Duta British di Manila bertajuk Claim To Sabah, 7 Julai 1978.

Ibid.

Ibid

Deed of Claim of Ownership To North Borneo (Sabah) Territory, 12 November 1978.

$47 \quad$ Ibid.

48 Selepas kawasan Pantai Timur Sabah berjaya dikuasai Kesultanan Sulu, ia kemudiannya diserahkan kepada Alexander Dalrymple sebagai konsesi sementara. Ibid. Rujuk juga MohdAriffHj. Othman, Tuntutan Filipina Terhadap Sabah, Kuala Lumpur: Dewan Bahasa dan Pustaka, 1988.

49 Menurut penjelasan yang diberikan, pada tahun 1769 Sultan Sulu, Sultan Alimuddin I telah menghantar anaknya Sultan Muda Mohammad Israil I dan para panglima Sulu ke Sabah. Setibanya di Sabah, angkatan Sultan Muda Mohammad telah diserang oleh Orang Tirun dan dikatakan berlaku pertempuran yang hebat di antara kedua-dua kumpulan tersebut. Akhirnya, panglima-panglima Sulu tersebut berjaya memenangi pertempuran sekali gus mengambil alih penguasaan Orang Tirun di Sabah. Semenjak peristiwa itulah penduduk Sabah mula membayar ufti kepada Sultan Muda Mohammad Israil I yang kemudiannya dianugerahkan pemilikan sepenuhnya dan berkekalan ke atas seluruh kawasan di Sabah oleh ayahandanya Sultan Alimuddin I. Ibid. 
K. G. Tregonning, The Philippine Claim to Sabah, hlm. 162 - 166. Lihat juga Low, H. 'Selesilah' dalam Papers Relating To Brunei. Malaysia: The Malaysian Branch of the Royal Asiatic Society, 1998.

51 Deed of Claim of Ownership To North Borneo (Sabah) Territory, 12 November 1978.

52 Ibid

53 Surat Duta British di Manila, A. T. Baillie kepada Southeast Asia Department bertajuk The Southwestern Philippines Problem, 12 September 1978.

54 Surat A. T. Baillie, Pejabat Kedutaan British di Manila kepada R. N. Pierce, Southeast Asian Department bertajuk Southwestern Philippines Muslim Problem, 29 Mei 1978.

55 Surat Duta British di Manila, A. T. Baillie kepada Southeast Asia Department bertajuk The Southwestern Philippines Problem, 12 September 1978.

56 Ibid. Ketika Sabah di bawah pemerintahan Tun Datu Mustapha dari tahun 1967 sehingga 1975, beliau dikatakan telah membawa masuk masyarakat Muslim Filipina ke Sabah dari 38.7 peratus sehingga 53 peratus. Lihat Robert O. Tilman. The Centralization Theme In Malaysia Federal State Relations, 1957-1975, Singapore: Institute of Southeast Asian Studies, 1976, hlm. 51. Beliau juga turut memberikan bantuan termasuklah dari aspek material, logistik, penempatan, pembelian peralatan dan senjata perang serta sokongan moral kepada pejuang-pejuang Moro di Selatan Filipina khususnya menerusi kumpulan pemisah MNLF. Rujuk AstriSuhrke dan Noble, L. G., (Eds.). Ethnic Conflict In International Relations, New York: Praeger Publishers, 1997, hlm. 183. Lihat juga W. K. Che Man, Muslim Separatism: The Moros of Southern Philippines And The Malays of Southern Thailand, hlm. 83.

57 Surat Duta British di Manila, A. T. Baillie kepada Southeast Asia Department bertajuk The Southwestern Philippines Problem, 12 September 1978.

58 Libya juga turut memberi janji akan membatalkan sokongan dan bantuannya kepada masyarakat minoriti Muslim di Selatan Thailand bagi menghormati hubungannya dengan Kerajaan Thailand. Surat R. P. Flower, Pesuruhjaya British di Kuala Lumpur kepada B. Smith, Southeast Asia Department, 25 April 1978. Ibid. 